\title{
The Important Role of Process Evaluation Mechanism in College English Teaching

\author{
Guan Xiang-feng
}

Faculty of Foreign Languages, Huaiyin Institute of Technology, Huaian, 223003, China

Email: guanxiangfeng01@126.com.

Keywords: American examining system of courses at college ; institutions of higher learning ; evaluating system in the course of teaching ; final exams ; creativity

\begin{abstract}
In the long run, institutions of higher learning in our country emphasize the results of final exams in their evaluating system, and neglect the links of assessment in the teaching process, which results in the students' slack and muddle phenomenon in their daily study. Nevertheless, before final exams ,they burn their mid-night oil to make a concentrated effort for their revision so as to get better results.This examining system , for one thing ,can only whet the evil style of study ,namely ,paying no attention to the accumulation of knowledge and improvement of their abilities in daily study ; for another ,it can not examine students' receptive and comprehensive abilities. Thus, this examining system must be reformed. This essay first introduces the American examining systems of courses at college, and then, the author combines the teaching laws of foreign languages and puts forward some suggestions that traditional standard mode of examining system be smashed; creative and manifold evaluating mode such as abridging and adapting of texts learned; report on reading; dub episodes of films and TV series; performance of short plays and introduction to scenic spots altogether in English etc. be adopted .
\end{abstract}

\section{Introduction}

Assessment is an important link in teaching activities, it is both an important way to check the students' mastery of comprehensive knowledge of the course , and to examine the teacher's teaching quality and the effects of teaching [1].The majority of colleges and universities abroad have established a set of course assessment modes which are suitable and scientific for their own teaching concept and characteristics after many years of teaching practice, while the widely adopted course examination modes in domestic colleges and universities are unitary, less scientific, procedural and systemic. From the course "Honors in French literature" in Brown University in the United States, we can get to know the characteristics of American university course assessment modes, and combine them with the language teaching law, and hence put forward some proposals for the college English teaching process assessing mode and course examination reform .

\section{The characteristics of American university course assessment mode}

In the 1970s, the American education expert, Sandy, put forward the principle of modern talent assessing mode, after he had summarized the predecessors' theories and teaching practice, who had transformed the emphasis from the traditional unitary examination at the end of the course to the cooperative and the process assessment in the process of course learning [2]. This kind of assessment mode has been adopted in the course "Honors in French literature", which embodies the following features:

1. Teacher will tell the students clearly about the course assessment mode even from the beginning of the course

Teachers will give out course requirements to the students at the first class, including the introduction of the course, the purpose of learning the courses, references, course organization, course requirements, performance standards, classroom teaching requirements, and the way to contact the teachers and teaching assistants.

2. The course assessment has diverse forms 
American universities pay special attention to process assessment, thus they do not adopt integrated mode of test paper evaluation, but in each stage, teachers arrange appropriate assessment mode, which could fully excavate students' potential and innovation ability in diverse mode, the course assessment mode includes case study paper, term paper, two tests, group discussions and class participation, etc. Among them, the results of two written tests account for only $30 \%$ of the total performance, and case study paper and term paper account for $50 \%$, group discussions $10 \%$ and class participation 10\% respectively . As for this assessment mode, students will not only focus on the final written examination, but the integrated use of all kinds of abilities in the process of learning to improve the ability of independent learning. They think that good assignments can provide opportunities for students to use a theory or concept outside the controllable class, and stimulate the students' freedom to release their divergent thinking [3].

3. The assessment presents its continuity to ensure each stage has a clear objective

Course assessment in American universities are arranged at various stages of course learning. In different teaching process, there are different assessing methods. When teachers arrange process assessment in each stage, they could combine their course requirements so that they can constantly urge students to maintain consistent learning attitude. Take "Honors in French literature" for example, this course starts on January 19 and ends on May 6th, in which period students must submit a case study paper on February 16, a term paper outline on March 2, the first test is on March 11, submit a term paper on April 13, there are five group discussions, and the second test is on May 6. Students have learned each testing time and testing methods from the very beginning of the course, therefore, they are always absorbed in their learning, dare not be slack in their study.

4. Each assessment mode has a clear and detailed standard to ensure fairness

Although assessment mode is varied, American universities have clear and detailed evaluation criteria for various assessment modes or examination modes so as to ensure the fairness of each student's result. Take term paper for example, "Honors in French literature" course requires students to write a 5-6 page paper, which must contain French literary representative writer in a certain period of time, the background of writing, the writing characteristics of works, the comparison of the literary works among representative writers in the same period, and demand the students study the theme from the perspective of society, history, economy, ethics. Before submitting the term paper, students must first submit the title of the term paper. After the approval of the teacher, they can begin formal writing, and the term paper must be submitted before the stipulated date. In the process of term paper writing, the teacher, students and teaching assistants will have many discussions. Teaching assistants will tell students about reference annotation methods. With strict procedures, the quality of students' term paper could be greatly improved.

Another mode which is worth our learning is the group discussion, which adopts the mode of group debate in the field of this course. Students are divided into different groups and are arranged to state their opinion within 15 minutes, after that, they have debates between groups, and answer questions from the audience. Other students as audience have got evaluation forms; they will give their score to each group for their preparation and performance on the scene. At the same time, each member in the group has also got an evaluation form, he or she will give his or her score to the performance of other members including himself or herself in the discussion .

\section{The deficiency existing in the examination pattern for courses among colleges and universities in our country}

With the constant improvement of talent evaluation standard in our country, colleges and universities in our country have been carrying on the reform of the assessment mode, but with the influence of teaching content and a serious imbalance proportion between teachers and students after the expansion of colleges, universities and students, certain deficiencies still exist in course examination mode, which are mainly embodied in the following aspects:

1. The assessment mode is simple and unitary 
The course assessment mode is still given priority to written test paper with no reference to textbooks and other teaching materials. This mode is easy to operate, and to a certain extent can guarantee the objectivity and seriousness of the examination. But this unitary exam mode can not really reflect the students' practical ability .

2. This assessment mode overemphasizes final examinations, ignoring the process assessment

At present, many courses have adopted the combination of final examination and the process assessment mode, but the result of process assessment accounts for only a very small proportion of the final grades. This irrational proportion can only render students to slack their normal study and neglect process assessment, and put their full energy onto the final examinations .

3. The assessment mode is lack of detailed criteria

Although some courses have also adopted the assessment mode, such as paper writing and group discussion, evaluation standards can not be laid down in detail. Most teachers feel at a loss as how to operate these evaluation standards .

\section{Perspective for the mode of process assessment for college English course}

《The National Medium and Long-term Education Reform and Development Program》 (2010 2020), points out:" Innovate talents training mode, follow the law of education and talent developing mode, deepen the reform of education and teaching methods, explore a variety of ways so as to nurture all kinds of talents, from which top creative talents will emerge in large numbers." [5]. Based on the advanced experience of American universities, college English course assessment mode can be reformed from the following several aspects:

1. Change the current unitary examination mode and adopt diverse modes of assessment

Colleges and universities, as an important base of talents training, it is necessary to re-examine the principles and standards of talent evaluation, to analyze the problems existing in the current examinations, to explore a set of new examination modes in order to improve the teaching effectiveness and purposes, promote the students' talent and potential and achieve talents' training goal [6]. Therefore, as for the mode of college English course assessment , we should pay more attention to the ability of students' participation in classroom teaching, examine the students' innovative ability and team cooperation ability, change the present mode of unitary final examination . We may examine students' abilities in text abbreviations, text rewriting, writing book reports, playing roles in English dramas, panel debates and diverse assessment modes.

2. Increase the ratio of process assessment; fully mobilize students' learning enthusiasm

Directed at the present situation of higher proportion of final examinations, we should fully consider the characteristics of college English course is just a course of language , the focus of the process assessment in college is not vocabulary, grammar, and we should put the emphasis on the language application. Especially in the process assessment stage, we can cancel the standardized written tests boldly. We may assign students to dub films or TV plays, play roles in English dramas, act as tour guides to introduce scenic spots, various kinds of assessing modes. It is especially important to give teachers' independent teaching space, increase the ratio of process assessment, in which teachers have the right to decide. We'd better cancel the whole college or the whole grade examination in the process assessment on a large scale. We can have assessment in the form of a class. As for the proportion of process assessment and final examination, we can increase the process assessment proportion to $60 \%$, the final examination accounts for only $40 \%$.

3. Stipulate diverse assessment criteria according to different assessments or examinations

As mentioned above, if we adopt diverse assessment or examination mode in the process assessment, it is most likely to have the problem of how to define assessment criteria. In terms of assessment criteria, the author thinks that we should summon all the teacher to have discussions to stipulate more flexible framework criteria. After all, language application is flexible, so we can not stipulate the stereotyped criteria . 


\section{Summary}

As for the diversity and continuity of American university curriculum assessment and focus on the cultivation of students' comprehensive abilities , especially for the understanding and research of teaching and assessment concept, it is well worth our institutions of higher learning drawing on their experience for the examination or assessment reform, so as to improve the students' abilities of analysis , understanding and comprehensive qualities ,and to cultivate high-level innovative, applied talents.

\section{Acknowledgement}

My special thanks is to my colleagues for their help in the collection of data and materials in writing this paper.

\section{References}

[1] Hu Yi-bo,Wang Zhi-zheng. University Course Examination Reform [J] Higher Education BBS, 2005, (5)

[2] Han Feng. Seven American Criteria to Evaluate Students' Performance [N] China Science and Technology, 2001-02-21.

[3] Chen Li-shu, Han Jing. American University Course Evaluation Methods and Its Technical Support [J] Development and Evaluation of Higher Education, 2010, (26) : 2.

[4] Higher Education Department of Education Ministry. "College English Curriculum Requirements" [Z]. 2007.7.

[5] Zeng Qing-jun. Establish Evaluation System with the Target of Talent Training [N]. China Education Newspaper , 2010-05-26.

[6] Wang Jing. Research on University Course Examination Mode [J] Education Frontier(Theory Edition), 2010, (4). 